artigo $]$

\title{
Teatro de revista e representação social do feminino no início do século XX
}

Rerue theater and female social representation in early twentieth century

[resumo] 0 presente artigo trata de questões relacionadas ao desnudamento do corpo feminino em contraponto à tomada de espaço em cena pela mulher no teatro de revista. Considerando as transformações sofridas pelo gênero entre as décadas de 1920 e 1960, são abordados os trajes de cena usados por coristas e vedetes como norteadores desta investigação. São pesquisadas ainda as companhias de teatro de revista europeias que mais influenciaram o gênero no Brasil.

\section{[palavras-chave}

\section{teatro de revista; traje de cena;}

desnudamento feminino.

[abstract] The present work is about female denuding related to increasing valorization of actress in revue theater. Considering the transformations ocurred in this theatrical genre between 1920 and 1960, the costumes of girls and starlets are pointed like guide lines for this research. This paper also considers the European revue theater companies which had influenced the genre in Brazil.

[keywords] evue theater; costume design; female denuding. 
0 teatro foi a grande diversão da sociedade brasileira até o início do século XX. De acordo com Neyde Veneziano, mesmo não tendo sido levado a sério pela elite intelectual brasileira, o teatro de revista foi "o mais expressivo e fervilhante gênero nas primeiras décadas desse nosso ruidoso século XX" (VENEZIANO, 1991, p. 15). No centro do Rio de Janeiro, as casas de espetáculo ficavam lotadas com apresentações de revistas em até três sessões diárias.

Espaço de construção do ideário urbano, a revista era alimentada pelo cotidiano, ao mesmo tempo que era capaz de ditar modas e influenciar fortemente o dia a dia dos espectadores. Guardando uma relação muito íntima com os anseios e desejos de sua época, o gênero evoluiu em paralelo aos eventos citadinos, tornando-se uma espécie de projeção dos assuntos em voga no momento de sua apresentação. Embora o foco da produção revisteira se desse no Rio de Janeiro, a atividade se alastrou por todo o País, em capitais e interiores.

Gênero marcado por alto grau de improvisação, a revista se apoiava no jogo estabelecido entre a plateia e os atores, com destaque para os cômicos e as vedetes. Entre as décadas de 1920 e 1960, a cena revisteira sofreu diversas transformações, produzidas por diferentes empresários e influenciadas por espetáculos, gêneros e companhias estrangeiros. Nesse período, é possivel observar uma crescente tomada de espaço em cena pelas mulheres, seja na figura das vedetes, seja na das coristas, ao passo que se percebe um gradual desnudamento do corpo feminino nos espetáculos. Essa relação estabelecida entre o crescente valor atribuído às mulheres e o crescente desnudamento de seus corpos se configura como o ponto central de interesse deste artigo.

\section{0 teatro de revista no Brasil}

0 teatro de revista surge no século XVIII, nos teatros de feira ${ }^{1}$ de Paris: é a Revista de Fim de Ano. Recebe esse nome por "passar em revista" os acontecimentos políticos, econômicos e culturais mais relevantes ocorridos ao longo do ano. Da França segue para outros países da Europa, sendo rapidamente adotado e difundido em Portugal, e dai chega ao Brasil. Mesmo aportando em terras brasileiras trazido pelos portugueses, o gênero mantém ainda por várias décadas a estrutura francesa. Aos poucos, vai conquistando o público, ganhando mais e mais espaço nos palcos brasileiros e tomando contornos próprios. 0 teatro de revista foi se diferenciando dos outros sistemas dramatúrgicos e firmando sua estrutura e suas convenções enquanto gênero de teatro musicado específico por meio das linhas mestras indicadas pela dramaturgia. Era um gênero teatral que problematizava o cotidiano, expondo as questões sociais e políticas de forma caricata e paródica, com personagens-tipo, números de dança e canto, esquetes e apoteoses.

No Brasil, foram necessárias algumas décadas para que o gênero ganhasse força. As primeiras tentativas não foram bem recebidas pelo público. A primeira revista apresentada no Brasil foi As surpresas do sr. José da Piedade, de Justiniano de Figueiredo Novaes, em 1859. Porém, considera-se como marco inicial do teatro de revista brasileiro o espetáculo 0 mandarim, de Arthur Azevedo, apresentado em 1884. 0 próprio Arthur Azevedo já havia feito algumas tentativas fracassadas com o gênero no Rio de Janeiro, mas foi somente após viajar para a Europa e assistir às Revistas de Ano francesas originais que o autor conseguiu atingir o público brasileiro, tornando-se um dos mais importantes comediógrafos de sua época.

Em um primeiro momento, a revista era estruturada com as figuras do compadre e da comadre, que eram articuladores do enredo, inter-relacionando os quadros e as cenas e respeitando um fio condutor. Era dividida geralmente em três atos, um prólogo e apoteoses no final de cada ato, entremeado por inúmeros quadros. As apoteoses eram autônomas em relação ao enredo, e geralmente a primeira apoteose era a mais importante. Esse ainda era um modelo bem francês. Aos poucos, a revista vai perdendo essa estrutura e adquirindo novos formatos. 0 compromisso com um fio condutor, mesmo que tênue, foi sendo abandonado, e foram desaparecendo as personagens do compadre e da comadre. As figuras femininas de vedetes e coristas 
ganharam projeção na cena. Com a Primeira Guerra Mundial, a revista tende a se nacionalizar, estreitando os laços com a música popular. Tania Brandão avalia que, com essa aproximação - que levou aos palcos compositores, instrumentistas, intérpretes e passistas -, torna-se "notável o papel da revista no universo ideológico-sentimental da cidade" (BRANDÃO, 2006, p. 3).

Uma das principais caracteristicas do teatro de revista era sua relação com a atualidade. De acordo com Collaço (2008b), esse "presentismo" é o que torna o gênero tão peculiar, mas ao mesmo tempo é um obstáculo ao seu entendimento nos dias atuais. As novidades, os eventos da atualidade, os grandes eventos sociais eram a matéria-prima da revista. 0 sucesso dos espetáculos se dava, em parte, pelo grande poder de comunicação com a plateia que os atores e as atrizes exerciam. As situações do dia a dia eram apresentadas em linguagem popular, fortalecendo o vínculo com o público.

Outra característica importante é a forte codificação da cena, começando pela demarcação de palco e chegando aos atores, organizados nas companhias a partir da hierarquia artística ${ }^{2}$ respeitada à época. Angela Reis afirma que, "além de ser voltada para a cena, a dramaturgia baseava-se na especialização dos atores: cada companhia possuía um naipe de atores que, a partir de características físicas e psicológicas, especializavam-se em determinados papéis" (REIS, 1999, p. 82), e apresenta os papéis descritos por Visconti Coaraci, em 1884:

0 galã - sua simpatia e honestidade venciam tudo, mesmo quando ameaçado pela mulher perigosa, vítima do próprio coração largo (...);

0 galã-cômico - ligeira variação do galã romântico. Apesar de fazer rir, conquista a plateia e a heroína;

0 pai-nobre - típico chefe de família incorruptível e respeitador (...);

0 tirano ou cínico - falsos amigos ou intrigantes que muitas vezes precipitam a ação da peça (...);

A ingênua - personagem sem maldade nem astúcia. No século $X X$ muitas vezes eram as primeiras atrizes da companhia (...);

A dama galã - mulher fatal, não necessariamente má, mas acostumada ao mundo e aos homens (...);

A dama central - equivalente do pai-nobre, cheia de ternura, dignidade ou dureza (...);

A caricata - (...) faz rir pelo comportamento ridículo e sem compostura; A lacaia - descende da serva e da colombina do século XVI. (REIS, 1999, p.82)

Em comparação à descrição acima, referente ao século XIX, vejamos as definições apresentadas por José da Silva Aranha, em 1949:

Estrela - é a $1^{\text {a }}$ figura feminina. Desempenha o papel principal na peça; Astro - é a $1^{\text {a }}$ figura masculina. É o personagem que contracena com a estrela;

Galã - artista que desempenha papéis jovens. Pode ser dramático, cômico, cínico ou amoroso (...);

Centro - é o ator que se encarrega dos tipos com idade um pouco avançada. Há o "centro" dramático, cínico e cômico;

Genérico - é o artista que se distingue por um só tipo de representação, mas que tem apetidões (sic) para desempenhar qualquer gênero de papel;

Utilidade - são atores que embora possuindo pouco valor, se incumbem de qualquer papel, sem desmanchar o conjunto. (ARANHA, 1949, p. 30) 
Tal distribuição era fundamental para o sucesso das companhias, que seguiam à risca a convenção, como podemos observar na fala de Rangel: "Ainda no que concerne à distribuição dos papéis, tendo em vista as convenções intransigentes da Arte, não pode o ensaiador alhear-se à exata concordância do físico exigido pela personagem, com o do artista a ser designado para interpretá-la" (RANGEL, 1954, p. 29).

Portanto, cada ator ou atriz de uma companhia desempenhava um papel que não variava ${ }^{3}$, relacionado com sua idade e seu físico, e, dessa maneira, seguia um modo de interpretar, um repertório de gestualidades condizentes com o papel desempenhado. A cada papel correspondiam uma série de personagens-tipo, esses sim, variáveis. Neyde Veneziano esclarece:

Diferente de outras modalidades, revista é um gênero teatral fragmentado que se adapta ao país no qual se aloja. É francesa se feita na França, portuguesa se for em Portugal, e assim por diante. Isto porque 0 arcabouço textual revisteiro se apresenta totalmente elástico, com espaços para os fatos do cotidiano local, para o desenvolvimento de personagens-tipo de cada país e para a inclusão de músicas nacionais. Dessa forma, a estrutura da revue $d u$ fin d'année, cujo enredo simples facilitava a inclusão dos assuntos locais, chegou ao Brasil e foi, imediatamente, povoada de malandros, mulatas, caipiras, portugueses. Juntaram-se a estes tipos acontecimentos sociais e políticos e, sobretudo, nossa música popular. A receita funcionava sempre e o gênio criativo do autor determinava a qualidade e a aceitação do espetáculo. (VENEZIANO, 2010, p. 55)

A escrita cênica era pensada e construida a partir desses preceitos. Quando uma companhia escolhia um novo texto para ser montado, automaticamente cada ator já sabia que personagem desempenharia, de acordo com seu papel, sua posição ocupada na companhia. Como não havia dúvidas a respeito da distribuição dos personagens entre os artistas, a função do ensaiador era, na maioria das vezes, apenas organizar entradas e saídas de atores, também respeitando a codificação do espaço físico do palco, como vemos na figura 1.

Figura 1: Marcação do palco

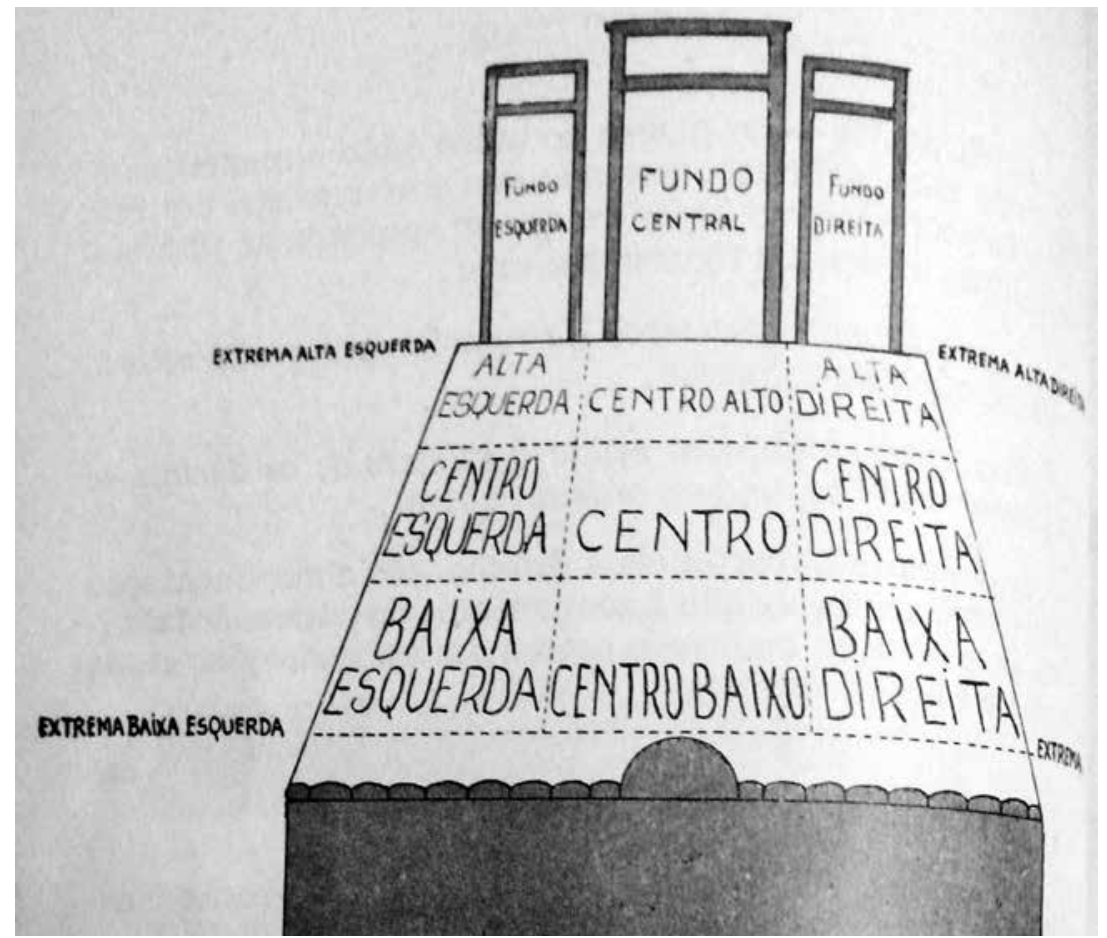

Fonte: ARANHA, 1949, p. 25. 
Essa divisão precisa do palco serviria para distribuir os atores em cena em locais mais ou menos privilegiados, também considerando a hierarquia estabelecida pela posição que cada artista ocupava dentro da companhia. Desse modo, garantia-se que os primeiros atores sempre estivessem em posição privilegiada em comparação àqueles que desempenhavam papéis de menor importância. Essa composição espacial era pensada de modo a favorecer a comunicação entre os comediantes e a plateia, sendo tal interação característica fundamental do gênero.

A revista traçava um panorama do que havia acontecido no ano anterior em várias áreas, destacando os principais fatos "relativos ao dia a dia, à moda, à política, à economia, ao transporte, aos grandes inventos, aos pequenos crimes, às desgraças, à imprensa, ao teatro, à cidade, ao país" (VENEZIANO, 2013, p. 128). Tratava dos assuntos cotidianos em linguagem popular, teatralizada. A crítica política era feita de maneira cômica, criando sátiras e paródias que envolviam o espectador. Assim sendo, a força do gênero estava "nas mãos do dramaturgo, no desempenho do cômico brasileiro e, principalmente, nas construções de efeito paródico" (VENEZIANO, 2010, p. 55).

0 traje de cena de vedetes e coristas

Collaço (2008b) afirma que até o início do século XX,

o trocadilho e a possivel alusão ao sensual e ao sexual estava colocado na palavra e não no gesto, portanto, não estava no corpo, e muito menos no corpo feminino. (...) a força do palco estava centrada na figura masculina, especialmente nos atores cômicos. (COLLAÇO, 2008b, p. 4)

Ao analisar o traje de cena das coristas nessa época, Collaço (2008a) afirma que o corpo das mulheres estava bastante protegido pelo uso de meias grossas, decotes discretos e poucos adornos apelativos. 0 corpo das mulheres já era considerado exposto para o período, porém, caberia ao potencial espectador ampliar, por meio de seu imaginário, a nudez que, em cena, era restrita aos braços e tornozelos despidos (Figura 2).

Figura 2: Grupo de coristas do Teatro São José, 1915

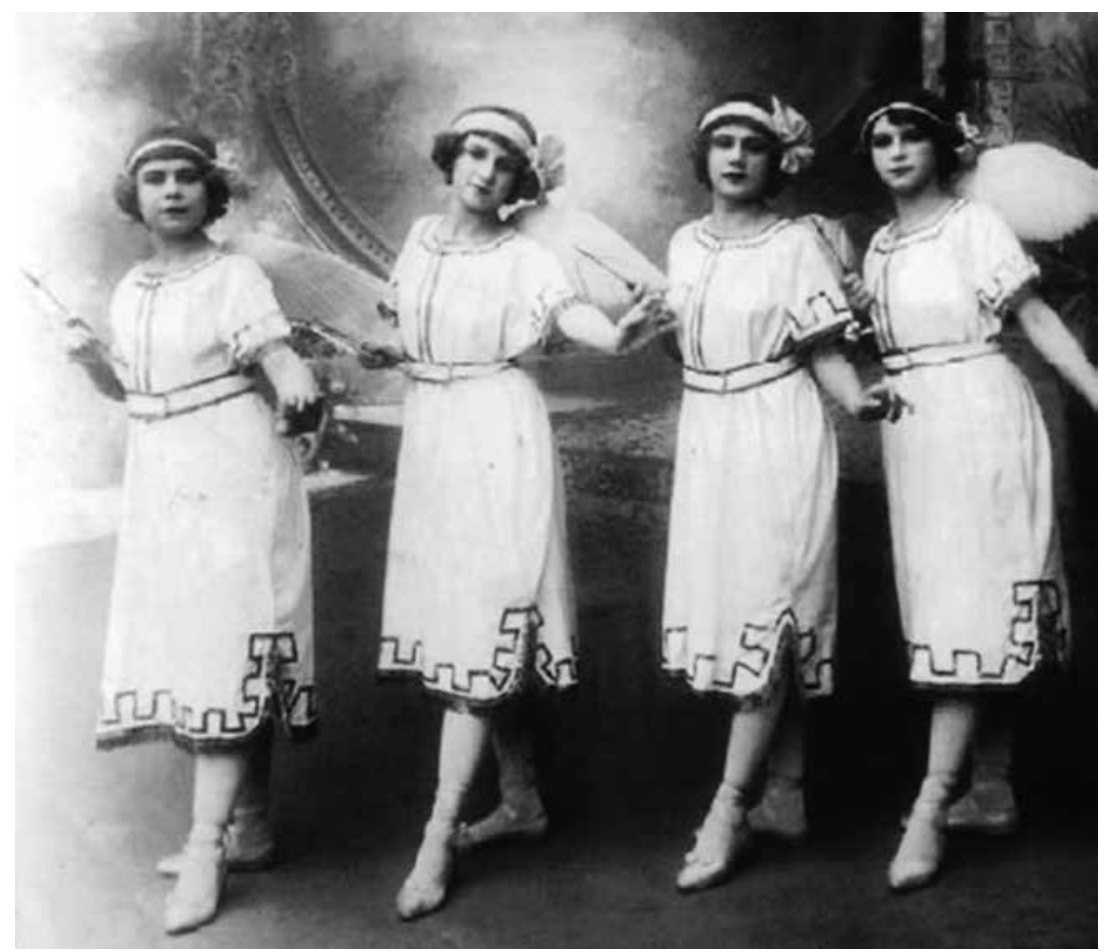

Fonte: CASCAES, 2009, p. 36. 
Veneziano (2011) e Collaço $(2008 a, b)$ apontam a década de 1920 como o início de mudanças significativas em relação à posição da mulher no palco revisteiro. Destaca-se a valorização da participação feminina nos espetáculos. As vedetes e coristas ganham espaço em cena, mas, em contraponto, perdem a roupa...

0 teatro de revista brasileiro sofria grande influência dos espetáculos estrangeiros, sobretudo europeus. No início dos anos 1920, o Brasil recebeu a visita de duas grandes companhias de revista: a Bataclan, francesa, e a Velasco, espanhola. Tais grupos foram responsáveis por significativa transformação nos rumos do gênero teatral.

\section{Bataclan}

Dirigida por Madame B. Rasimi (Figura 3), a companhia do teatro Bataclan de Paris fez sua estreia em terras brasileiras em 5 de agosto de 1922, no Theatro Lyrico (RJ), trazida pela Empreza Theatral José Loureiro. 0 espetáculo apresentado foi Paris-Chic. A turnê pela América do Sul incluiu, além do Brasil, a Argentina e o Uruguai, e os jornais locais transmitiam as notícias mais recentes sobre a trupe e suas apresentações nos países vizinhos, já adiantando o sucesso que deveriam esperar. Além de Paris, a trupe só havia se apresentado até então em Londres e Nova York. Desse modo, é possivel imaginar o alto investimento feito por José Loureiro para que o Brasil recebesse a companhia estrangeira, e a importância dada pelo empresário em manter o país (principalmente as cidades do Rio de Janeiro e de São Paulo) afinado com o que havia de novo e exuberante no mapa teatral mundial do período.

Como era de costume à época, os jornais anunciavam euforicamente a vinda da companhia com meses de antecedência. Eram divulgadas imagens de propaganda da trupe, detalhes dos figurinos, fotos das vedetes e bailarinas mais aclamadas, e mesmo a seleção de quadros e cenas dos espetáculos, o que servia para alimentar a imaginação do espectador e tornar a estreia ainda mais desejada. No

Figura 3: Madame B. Rasimi

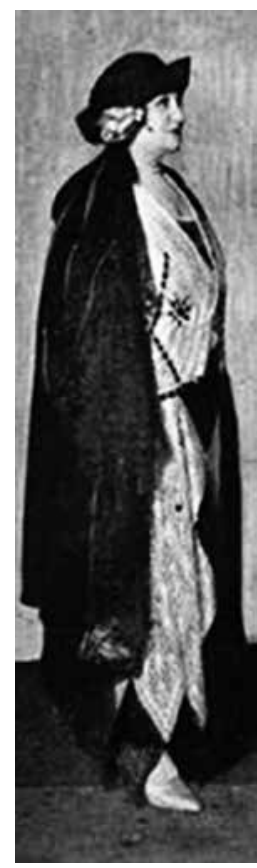

Fonte: Revista FonFon, 5 agosto de 1922 . Jornal do Brasil, o Bataclan era chamado de "Rainha das Revistas", pois era "a melhor, a mais luxuosa e a mais cara, mas também a mais admirada e a mais surprehendente de todas as companhias parisienses do genero (...) nenhuma excede em fantasia as de Madame Rasimi" (JORNAL DO BRASIL, 27 de junho de 19224).

Havia também aqueles que consideravam o teatro de revista um gênero menor e desacreditavam a vinda da companhia francesa ao Brasil. 0 crítico Benjamin Costallat afirmou, na edição de 14 de julho de 1922 do Jornal do Bra$\mathrm{sil}^{5}$, que o grande mérito dos espetáculos do Bataclan era a nudez das belas parisienses. Segundo o crítico, as artistas não eram geniais, e nos papéis que desempenhavam, as pernas eram mais importantes que o cérebro. Segundo sua argumentação, a censura no Brasil seria mais rígida do que em Paris, por isso as artistas aqui estariam mais vestidas, o que descaracterizaria completamente o gênero; e ainda julgava que as belas atrizes parisienses não perderiam seu tempo em viagem até aqui, logo seriam substituídas por atrizes cariocas já conhecidas do público, o que tornaria a companhia francesa um verdadeiro blefe. Contrariando as expectativas de Costallat, Madame Rasimi trouxe em sua trupe vários artistas, incluindo-se aí Randall, primeiro astro da companhia, Mlle. Missia, a vedete mais famosa (Figura 4), atores cômicos, diversas girls ${ }^{6}$ e as melhores bailarinas. Vieram ainda técnicos responsáveis pelo funcionamento do espetáculo, diversos cenários e uma quantidade exorbitante de figurinos (de acordo com os jornais, entre 2 e 3 mil trajes). Na passagem da companhia por Buenos Aires, a censura local considerou os espetáculos apropriados para menores, o que significava diversão para toda a família. 
Figura 4: Mlle. Missia e Mr. Randall, do Bataclan

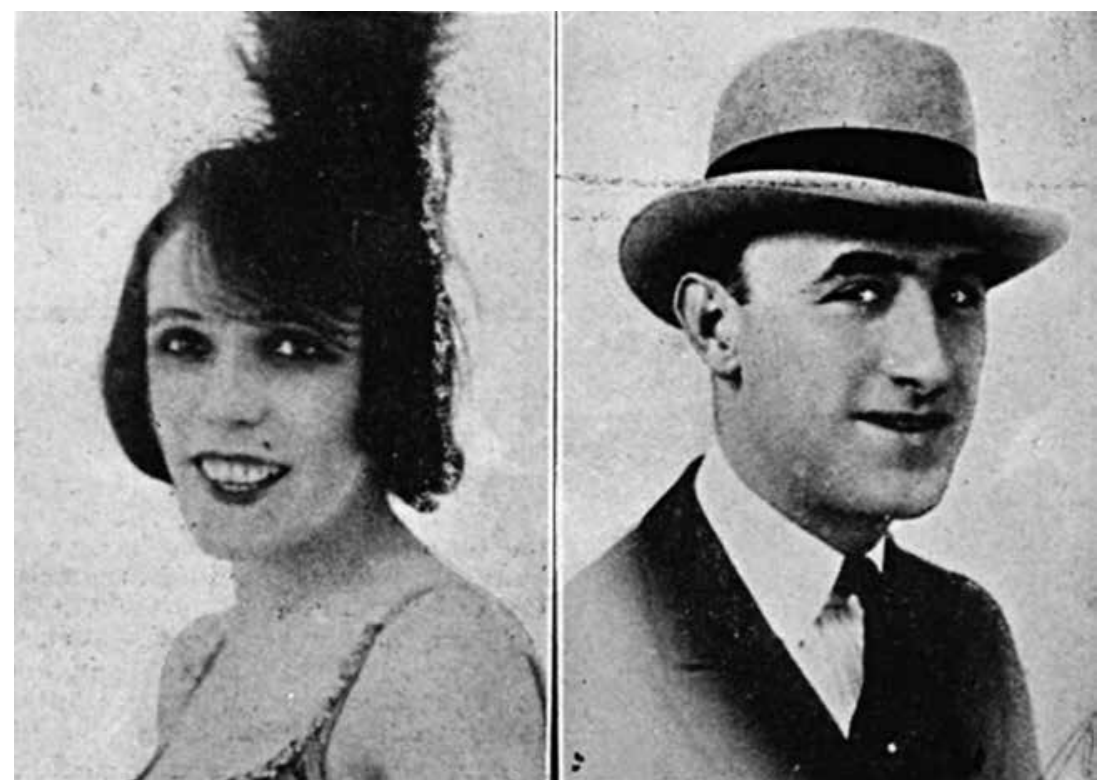

Fonte: Revista FonFon, 24 junho 1922.

Além de Paris-Chic, a Bataclan apresentou outros três espetáculos de seu repertório ${ }^{7}$ na temporada de 1922: Pour vous plaire, estreado em 15 de agosto, V'la Paris, estreado em 22 de agosto, e Au revoir, estreado em 30 de agosto. Em setembro, a companhia seguiu para São Paulo, onde apresentou os mesmos espetáculos entre os dias 6 e 22 de setembro de 1922, no Theatro Sant'anna.

0 teatro de revista francês era então o modelo que inspirava os demais. Eram franceses os melhores artistas, as melhores vedetes e girls, os melhores cenários e figurinos. 0 modelo francês era um padrão a ser seguido. $E$ se, por um lado, uma das inovações que a companhia trazia era a nudez de suas mulheres, por outro, os inúmeros trajes usados pelas artistas são citados como elementos principais dos espetáculos, assim como o luxo e o bom gosto com os quais eram confeccionados - mérito atribuído à diretora da companhia, Mme. B. Rasimi. A plateia era surpreendida pela qualidade dos elementos plásticos da cena e arrebatada pela interação entre a luz, a música e a entrada em cena dos artistas.

Paris-Chic recebeu boas críticas após sua estreia no Rio de Janeiro. Mário Nunes ${ }^{8}$ destaca, em crítica publicada no Jornal do Brasil de 6 de agosto de 1922, aspectos referentes ao vestuário usado em cena pelas mulheres, ao bom gosto de Mme. Rasimi ao apresentar o melhor da moda parisiense, à beleza das mulheres e à comicidade dos atores, e descreve o encantamento causado pelo espetáculo, em virtude das "novas e incandescentes libações durante três horas consecutivas de música e de movimento multicor e irisado". 0 crítico destaca também a qualidade dos espectadores, homens e mulheres muito bem-vestidos, cultos, intelectuais, que lotavam a sala do Theatro Lyrico. Contudo, destaca que havia nas galerias um grupo de pessoas que chefiava uma injusta assuada. Afirma que tal desordem não teve resultado, já que o espetáculo terminou com estrepitosos aplausos advindos da esmagadora maioria do público, que o autor considerava "gente sensata".

É muito interessante notar, na crítica de Mário Nunes, de que maneira o espetáculo oferecido pela Bataclan trazia a mulher como atrativo máximo, cujo objetivo era agradar ao público masculino e ao feminino também. Aos senhores estava garantida a exaltação e a admiração causadas pela beleza das vedetes e girls, e, claro, a nudez assumida dessas mulheres. Às senhoras, restava apreciar a harmonia e o encanto das atrizes em cena, que cantavam e dançavam com elegância e graça, servindo de pretexto para a criação de modelos de fantasias pautados pelo inconfundivel bom gosto 
parisiense. 0 corpo feminino despido aqui parece ser encarado pelo crítico como um contraponto, um complemento aos muitos e luxuosos trajes, e essa complementaridade é parte da esplendorosa fantasia trazida à cena por Mme. Rasimi.

Nunes se refere às cenas cômicas e aos bailados também, contudo esses elementos apenas multiplicam o deslumbramento causado pela figura feminina e pelo vestuário colorido e harmonioso. Importantíssimo destacar ainda a diferença encontrada nas críticas em relação aos elogios que se dirigiam aos atores ou às atrizes. Os artistas homens de maneira geral eram congratulados por causa do profissionalismo que exibiam, por sua capacidade de atuação e por possuir veia cômica acentuada. Já as mulheres eram, na grande maioria das vezes, enaltecidas por sua beleza, por seus dotes físicos ou pelos trajes que usavam (que, por sua vez, tinham a função de torná-las belas). Os atores homens reuniam diversos atributos, e a beleza não necessariamente precisava estar entre eles. Às mulheres, era imprescindivel ser bela, e isso praticamente bastava. 0 crítico considerava a mulher como o principal elemento de êxito da revista, e atribuía a ela a função de "inflamar, exaltar a admiração dos homens"10. De um modo geral, se percebe, com a leitura de críticas e matérias publicadas nos jornais em 1922, que os atores cômicos eram muito valorizados e aplaudidos, mas uma companhia teatral que contasse com belas atrizes e belos trajes estaria equipada com a "condição necessária e suficiente para agradar a ambos os sexos"11.

Assim como Paris-Chic, os outros espetáculos da trupe foram recebidos com animação e euforia por plateias quase sempre lotadas. Ao fim da temporada, o público já nutria afeição pelos artistas e personagens, a ponto de Mário Nunes afirmar, em crítica do espetáculo V'la Paris, que se a estadia da companhia fosse mais prolongada, os artistas tornar-se-iam figuras muito populares ${ }^{12}$.

Se os jornais ${ }^{13}$ do Rio reportavam sucesso absoluto da trupe, em São Paulo não foi bem assim. 0 Correio Paulistano reiterava as informações divulgadas pelos jornais cariocas, porém os periódicos 0 Combate $A$ Vida Moderna julgavam os espetáculos da trupe imorais, não adequados à diversão da família paulistana, e exibiam a preocupação constante em relação à má influência que exerceriam especialmente sobre as mulheres. Outra reclamação encontrada diz respeito ao preço exorbitante cobrado pelos espetáculos. De toda maneira, no ano seguinte, a companhia voltou para mais uma turnê pela América do Sul, e Rio de Janeiro e São Paulo novamente estiveram entre as cidades visitadas.

Na temporada de 1923, as expectativas do público carioca eram ainda maiores. A estreia contou com o teatro Lyrico lotado, mas já não havia tanta novidade assim nos espetáculos. 0 primeiro espetáculo apresentado foi C'est la miss (Figura 5), e o crítico Mário Nunes considerou alguns quadros muito bons, enquanto outros foram apenas regulares. Destacavam-se os figurinos e cenários criados por Mme. Rasimi e a interpretação de Mistinguett, a vedete mais famosa da época. Em relação aos nus, o crítico afirmou que não iam além do que já era apresentado pelas companhias brasileiras ${ }^{14}$.

Figura 5: Apoteose de C'est la miss, do Bataclan

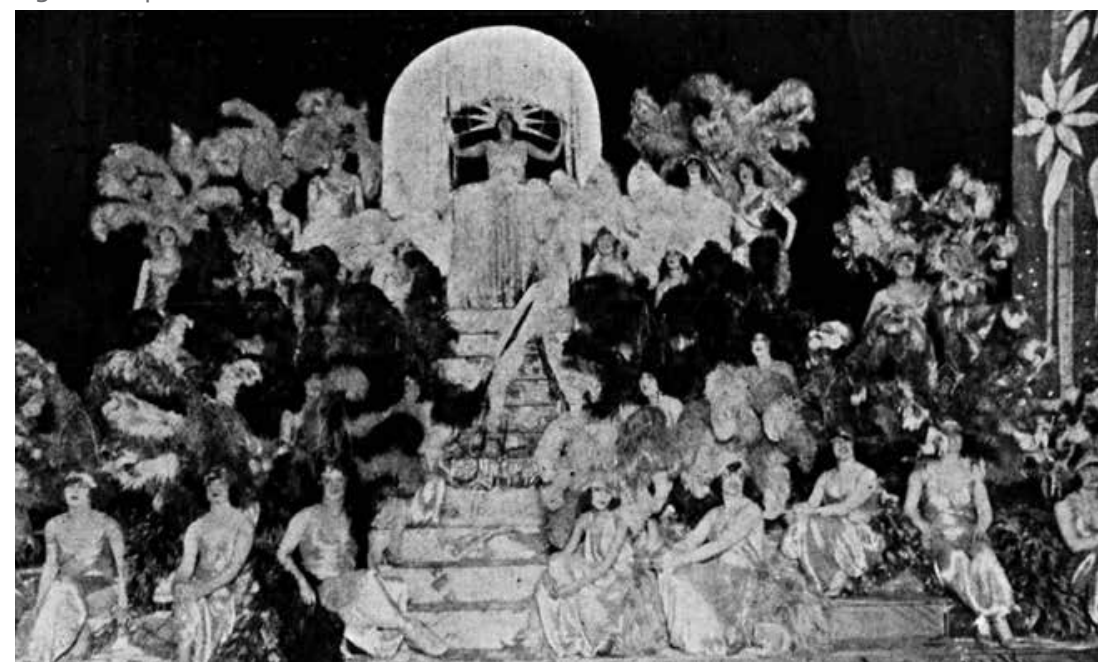

Fonte: Revista Fon Fon, 11 de agosto de 1923. 
Foram apresentadas, além de C'est la miss, as revistas La marche a l'etoile, Bonsoar e Oh!la!la!. Somente as duas primeiras contaram com a participação de Mistinguett, que era muito elogiada sempre, e havia sido muito aguardada pelo público carioca. A atriz deixou o Brasil no final das apresentações de La marche a l'etoile para honrar um contrato assinado anteriormente em Nova York. Com a partida da grande estrela, o sucesso da companhia ficou a cargo do primeiro ator, Randall, que acabava de chegar ao Brasil para juntar-se à trupe francesa e já era estimado pela plateia e pela imprensa, além da já afamada criatividade de Mme. Rasimi no tocante aos aspectos visuais da cena.

Além das sessões noturnas, chamadas de soirée, havia também apresentações vesperais (matinée), chás dançantes, festas artísticas e festas da moda, todas organizadas por Mme. Rasimi, e contavam com a participação de parte do elenco da companhia. Nas festas da moda, além da representação das revistas com quadros extras e novas canções, as vedetes e girls apresentavam à plateia trajes parisienses que seriam lançados nos próximos três meses. Como se vê, eram criadas maneiras diversas de estar em contato com o público. 0 lançamento de novidades era um dos chamarizes mais usados como mecanismo teatral para atrair a plateia e aproveitar toda e qualquer oportunidade rentável que a temporada pudesse propiciar. Cada revista da companhia ficou em cartaz por aproximadamente uma semana. A partir do quarto ou quinto dia de apresentação, eram inseridos na revista novos quadros, novas canções, inclusive contando com a aparição de atores brasileiros famosos e cenas que faziam menção à dramaturgia local, por exemplo. Dessa maneira, buscava-se levar ao teatro até mesmo aqueles que já haviam assistido ao espetáculo anteriormente, com a promessa de que agora a cena estaria completamente remodelada, conferindo uma nova experiência imperdivel aos fãs do gênero.

Após apresentar os quatro espetáculos, o Bataclan seguiu para São Paulo para mais uma temporada no Teatro Sant'anna. Antes, porém, foi a Santos, inaugurar 0 Theatro Casino Parque Balneário. A revista apresentada foi Bonsoar. Os jornais registraram elogios às toilettes, aos artistas e à plateia, fina e elegante, composta por membros da alta sociedade. Na capital, porém, a mesma revista não recebeu tantos elogios. 0 Correio Paulistano publicou crítica ao espetáculo reclamando da falta de novidade em cena. Randall recebeu muitos louvores da imprensa, já os outros artistas foram acusados de estar sem voz e sem charme. A propaganda de Bonsoar prometia levar a São Paulo as mais lindas mulheres de Paris, mas os jornais registraram uma profunda decepção com as girls. Nem mesmo a orquestra escapou, sendo acusada de oscilar em todos os números. Como essa foi a primeira das revistas apresentadas, ainda restava a esperança de que as outras três reservassem surpresas e melhores momentos à imprensa e ao público em geral.

A própria crítica do Correio Paulistano levanta uma hipótese para tal insucesso: sugere que após longa e estafante peregrinação por Buenos Aires e pelo Rio, as mais belas mulheres chegaram a São Paulo fanadas e murchas ${ }^{15}$... De fato, é provável que após passar por várias capitais encenando quatro revistas diferentes, e praticamente sem folga, todos os artistas e técnicos estivessem estafados, o que explicaria a falta de brilho das mulheres, de voz dos homens e de harmonia da orquestra. Outro aspecto importante foi a ausência de Mistinguett na temporada paulista, já que a vedete foi um dos pontos altos da temporada carioca. $E_{1}$ ainda, talvez a temporada de espetáculos realizada pela Companhia Velasco tenha ofuscado parte do brilho da Bataclan em São Paulo. A Velasco fazia então sua primeira turnê pelo Brasil, sendo muito bem recebida, e ficou em cartaz no Teatro Sant'anna até o dia anterior à estreia do Bataclan. Pode ser que as novidades trazidas pela trupe espanhola tenham agradado mais aos paulistanos do que a concorrente francesa... Já no Rio, as duas ganharam destaque positivo pela imprensa.

A Bataclan apresentou em São Paulo os outros três espetáculos da temporada, mas assim como Bonsoar, nenhum parece ter conquistado grande mérito junto à imprensa. Todo o destaque da temporada foi dado a Randall, e alguma atenção 
conferida aos trajes criados por Mme. Rasimi. Finalizando a temporada em São Paulo, a companhia voltou ao Rio, a fim de esperar o navio que a levaria a Salvador - última capital brasileira a ser visitada - para uma curta série de quatro apresentações. Como tais preparativos levariam muito tempo, foi iniciada nova temporada no Rio, dessa vez com ingressos a preços populares, e todas as revistas foram apresentadas novamente no Theatro Lyrico.

De acordo com as informações encontradas em jornais e periódicos, apesar do sucesso da segunda temporada não ter sido equivalente ao da primeira, a nova visita da trupe francesa serviu para consolidar as novas plásticas e técnicas teatrais que conquistaram os revistógrafos nacionais. Logo após o fim da primeira temporada da companhia, em 1922, já era possível perceber o tamanho da influência dos espetáculos criados por Mme. Rasimi nos palcos brasileiros. E para além dos palcos também.

Dentre as inovações trazidas pela companhia, as mais impactantes dizem respeito às mudanças referentes aos aspectos visuais da cena, sobretudo o figurino das vedetes e coristas. Ou à ausência de figurinos, em alguns casos. Revolucionando o nu artístico ao mostrar as pernas no palco, as girls da Bataclan obrigaram as coristas brasileiras a tirar as grossas meias que usavam. Além disso, as coristas francesas eram mais magras, exibiam figurinos padronizados e luxuosos, o que significava uma maior organização plástica do espetáculo.

A trupe francesa lançou "a revista brasileira na rota, até então não experimentada, da féerie ${ }^{16}$, na qual o luxo e a fantasia tornavam-se primordiais" (VENEZIANO, 1991, p. 43). Segundo Veneziano, "bem mais que uma companhia, a Bataclan foi um marco que determinou uma guinada na história do nosso Teatro de Revista" (idem, p. 44). A trupe fez história, e deixou rastros que culminaram na criação de outras companhias com moldes semelhantes no Rio de Janeiro: a Tro-lo-ló, de Patrocínio Filho e Jardel Jércolis (recém-chegado da Europa), e a Ra-ta-plan, dirigida por Luiz de Barros (ibidem, p. 44).

Mário Nunes, em crítica publicada em 21 de abril de 1923 no Jornal do Brasil ${ }^{17}$, assevera a decidida influência exercida pelo Bataclan no teatro ligeiro brasileiro. Tal crítica tratava do espetáculo Meia-noite e trinta, de Luís Peixoto, apresentado no teatro São José pela Companhia Paschoal Segreto. Mário Nunes considerou a revista como um passo dado à frente como concepção e como execução, na direção de uma desejada reforma do teatro popular.

Há o registro da estreia de uma Companhia Petit Bataclan em Santos (SP), em fevereiro de 1923; nos jornais, podiam ser vistas as propagandas de trupes brasileiras de teatro de revista que se promoviam como "companhias gênero Bataclan", inclusive nos teatros do subúrbio. De fato, além de influenciar uma transformação nos procedimentos técnicos e nas escolhas artísticas do teatro popular da época, a companhia francesa virou sinônimo de um tipo de fazer teatral; mais do que isso, a palavra Bataclan passou a sintetizar uma representação, que se relacionava a ideias inovadoras, a modernidade e a mulheres despidas, como não podia deixar de ser: "Bataclan é, hoje, o termo genérico para significar pouca roupa, preciosismo, situações em que a luz se expande em radiações multicolores, a 'feerie', o seminu artístico, um arremedo de arte, que delicia os olhos, enerva e abate" (JORNAL do BRASIL, 13 de janeiro de 1923) ${ }^{18}$.

Essa associação de imagens referentes à palavra Bataclan ultrapassou os limites da boca de cena e pôde ser encontrada nos meandros da vida social cotidiana do início da década de 1920. Ao pesquisar pelo termo Bataclan nos jornais cariocas e paulistas, encontram-se raras ocorrências antes do ano de 1922. Daí em diante, o termo pode ser encontrado nas mais diversas áreas, como pontuado a seguir:

As lojas de vestuário anunciavam calçados, trajes e acessórios "estilo Bataclan" (Figura 6). Na seção de cartas da revista Fon-Fon de 6 de outubro de 1923, o colunista dá às leitoras conselhos de moda: "Os chapéus para chás são pequenos - feitio 
ba-ta-clan, cloche, guarnecidos de florinhas vivas. Os sapatos e meias são de acordo com a cor da toilette. Tudo hoje é ba-ta-clan ${ }^{19 " . ~}$

Figura 6: Propaganda do sapato Bataclan

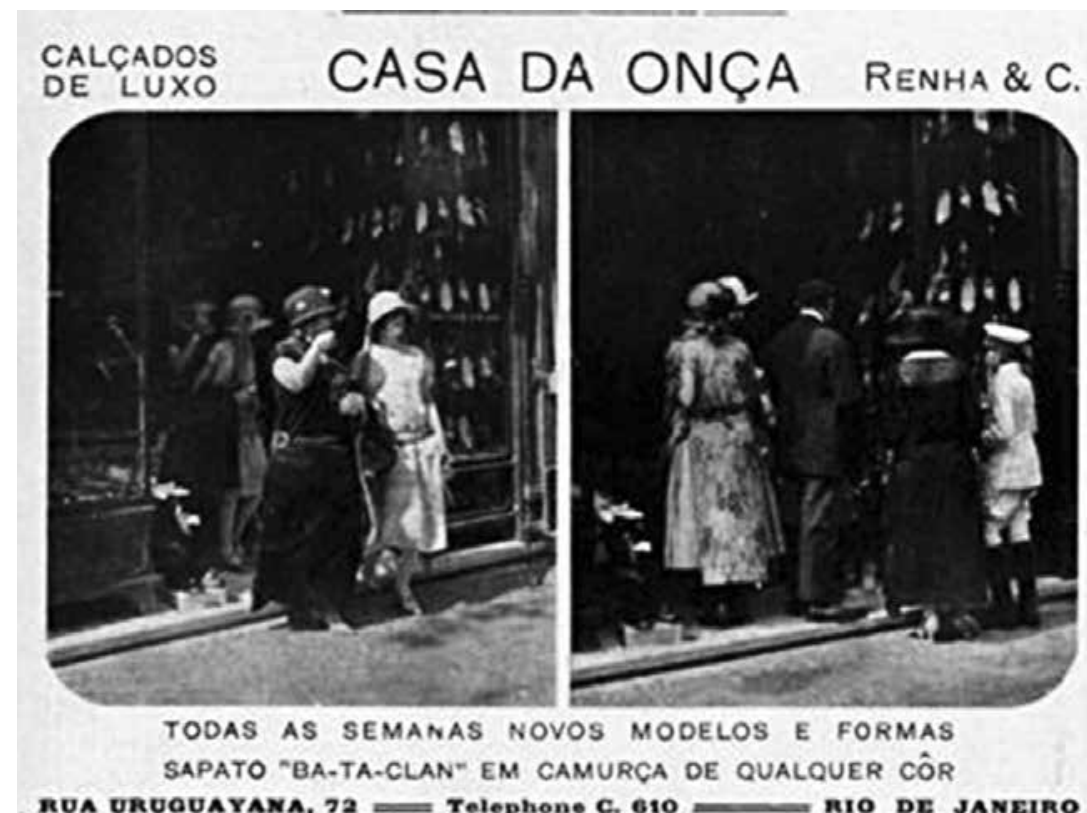

Fonte: Revista Fon Fon, 1 de setembro de 1923.

E ainda: time de futebol chamado Bataclan, hotel, banda de música, cavalo de corrida, prêmio destinado aos corredores de cavalo, curso de modelagem à distância, bebida engarrafada, jornal de pequeno porte no interior... Podemos perceber, dessa maneira, o quanto a passagem da companhia por terras brasileiras foi emblemática, especialmente para as artes cênicas.

\section{Velasco}

A trupe do Teatro Apollo de Madri veio ao Brasil pela primeira vez em 1923, após passar por Buenos Aires e Montevidéu. Dirigida por Eulogio Velasco, a companhia foi contratada pela Empreza Paschoal Segreto para realizar temporada no Teatro São Pedro ${ }^{20}$, no Rio de Janeiro, e no Teatro Sant'anna, em São Paulo. Mario Vitoria era o diretor artístico da companhia, que contava com um naipe de famosos artistas: Rosita Rodrigo, Maria Caballé, Clara Milan, Eugênia Galindo, Vicente Mauri e Antonio de Bilbao estavam entre os nomes de peso da Velasco.

Foram apresentadas nessa temporada duas revistas do repertório da trupe: Arco-íris e La tierra de Carmen. Curiosamente, Bataclan e Velasco vieram de Montevidéu para o Rio a bordo do mesmo navio, o Mendoza. Estrearam no mesmo dia, em 5 de agosto de 1923 - a Bataclan, no Theatro Lyrico, e a Velasco, no Teatro São Pedro -, e ambas as casas de espetáculo estiveram lotadas.

A crítica da estreia de Arco-íris publicada no Jornal do Brasil de 7 de agosto de 1923 chama atenção para o desfile de cores no palco, vestuários deslumbrantes, cenários luxuosos, um verdadeiro conto de fadas (Figura 7). Cita ainda a bela interpretação de todas as atrizes, dos cômicos e dos bailarinos, e a distinção da assistência, que lotava plateia e camarotes, conferindo ao antigo teatro uma "imponência rara"21. 
Figura 7: Apoteose da revista Arco-íris, da Velasco

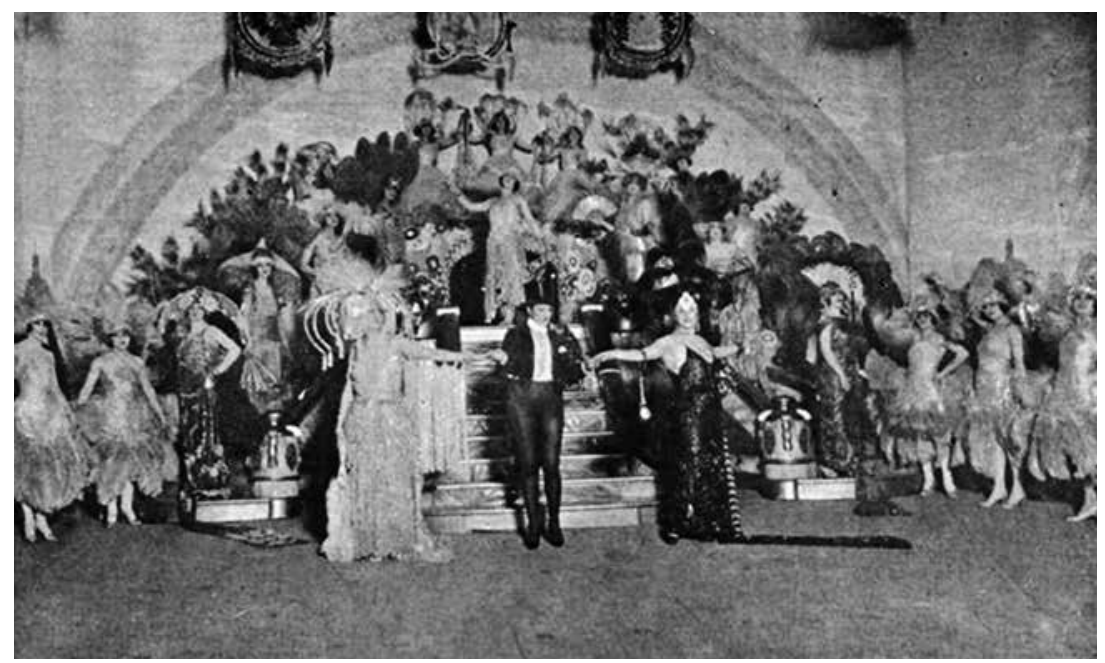

Fonte: Revista Fon Fon, 11 de agosto de 1923.

Assim como a Bataclan, a Velasco promoveu vesperais e festas artísticas com a participação das estrelas e dos astros da companhia. Cabe notar aqui que a trupe espanhola fazia questão de ter bom relacionamento com a imprensa e, com esse intuito, promoveu uma festa artística dedicada aos profissionais do ramo. Eugênia Galindo foi a responsável pelo evento, que contou com a apresentação de Arco-íris remodelada com novos quadros especialmente para a ocasião, e de maneira exclusiva, já que tais mudanças não seriam mantidas nas apresentações regulares do espetáculo. 0 ator Leopoldo Fróes também participou em números variados que formaram um aparte ao espetáculo, sendo esses já de conhecimento do grande público.

Tal estratégia era bastante utilizada pelas companhias estrangeiras: ao chegar a uma cidade, procuravam os artistas locais mais reconhecidos e criavam novos quadros nos espetáculos de modo a inseri-los na montagem. 0 formato do teatro de revis-

Figura 8: Rosita Rodrigo, da Velasco.

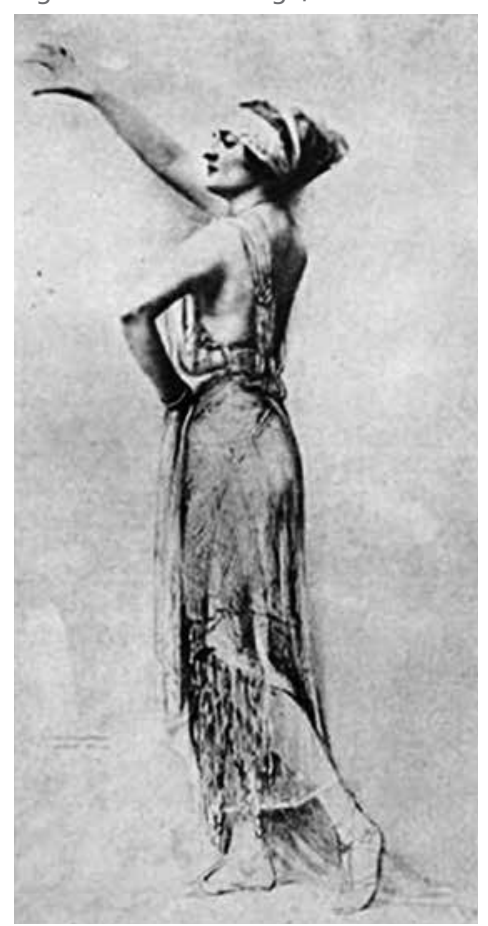

Fonte: Revista Fon Fon, 11 de agosto de 1923. ta facilitava e propiciava tais intervenções, sem prejuizo algum à cena, pelo contrário. Os quadros novos conferiam maior dinâmica à trama, alimentavam o espetáculo com novidades, seu maior combustível, e, mais uma vez, funcionavam como chamariz para o público que já havia assistido voltar ao teatro. Ainda em relação à atenção especial dada à imprensa pela companhia, vale notar que na última apresentação de Arco-íris no Rio de Janeiro foram oferecidas taças de champanhe aos cronistas durante o intervalo do segundo para o terceiro ato, ocasionando um momento de agradecimentos reciprocos entre jornalistas, artistas e empresários durante a sessão de teatro.

Além da festa artística dedicada à imprensa, realizada por Eugênia Galindo, a Velasco ofereceu ainda festa artística organizada por Clara Milani, com participação de Procópio Ferreira, e festa artística organizada por Rosita Rodrigo (Figura 8), com a participação do primeiro barítono da Companhia do Theatro Municipal do Rio de Janeiro, José Segura Tallien. 
Como cada festa era organizada por uma atriz diferente, todas garantiam uma possibilidade de ganhar a afeição do público, de modo que o sucesso da trupe não ficasse relegado a apenas uma artista.

A temporada de espetáculos realizada pela Velasco foi bastante distinta da realizada pela Bataclan. Como já exposto, a companhia francesa apresentou quatro espetáculos no Rio, foi a São Paulo, apresentou o mesmo repertório, voltou ao Rio e fez temporada popular mais uma vez, apresentando os quatro espetáculos. Já os espanhóis da Velasco trouxeram apenas duas revistas, Arco-íris e La tierra de Carmen (Figura 9). A primeira foi apresentada durante quase um mês no Rio (entre 5 de agosto e 3 de setembro de 1923) e, pelo que consta nos jornais, sempre com o teatro cheio. Depois disso seguiram para São Paulo, onde apresentaram os dois espetáculos, e regressaram ao Rio, para apresentar a segunda revista (estreada em 25 de setembro). Em São Paulo, a Velasco também promoveu diversas festas artísticas, organizadas inclusive pelos cômicos, além das vedetes.

Figura 9: Apoteose de La tierra de Carmen, da Velasco

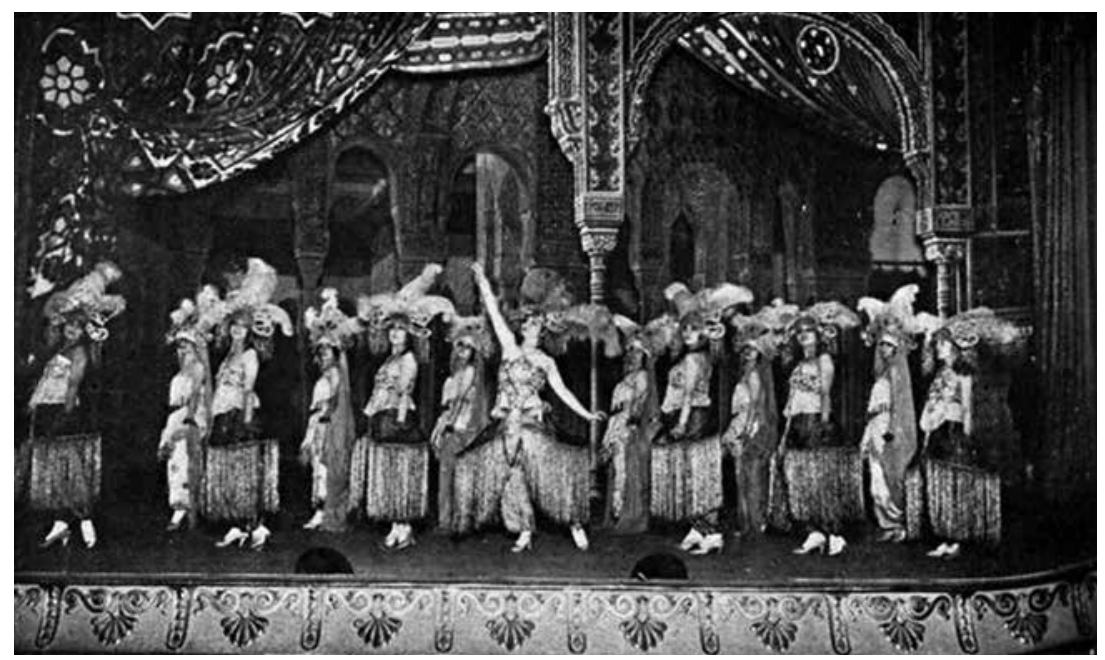

Fonte: Revista Fon Fon, 29 de setembro de 1923.

Tanto Arco-íris quanto La tierra de Carmen receberam críticas positivas no Rio de Janeiro e em São Paulo. Foram mencionados os belos cenários, os luxuosos figurinos, a atuação dos artistas, fossem atores, bailarinos ou músicos. 0 uso das cores chamou a atenção dos críticos e da plateia e, especificamente em La tierra de Carmen, os trajes típicos foram uma grande novidade que surpreendeu positivamente os espectadores. Não foram encontradas, nas pesquisas feitas nos jornais já mencionados, alusões à nudez das mulheres. Assim como nos espetáculos do Bataclan, as mulheres estão em muito maior número no palco do que os homens, ocupam cada vez mais espaços, recebem elogios em relação à sua beleza, simpatia, trato com a plateia, voz, afinação e comicidade, e pelos belos e requintados trajes que exibem.

Finalizando essa temporada, tanto no Rio quanto em São Paulo, as últimas récitas foram dedicadas a um espetáculo chamado A revista das revistas. Nessa apresentação, os melhores quadros de cada revista foram escolhidos e misturados para formar um novo espetáculo, composto somente pelos momentos mais aclamados pelo público. E ainda, em algumas dessas apresentações, as girls puderam atuar como primeiras atrizes, enquanto as vedetes faziam as vezes de coristas, numa divertida inversão de papéis que impressionava a plateia e imprimia à companhia uma agradável imagem de camaradagem entre seus membros. 
A Velasco voltou ao Brasil em 1924, dessa vez contratada por José Loureiro, e em 1925, contratada por N. Viggiani. Nas duas ocasiões, a turnê incluiu Rio de Janeiro, São Paulo, Bahia e Pernambuco. Em maio de 1926, o Correio Paulistano anuncia a falência da companhia, em Barcelona. Mas a essa altura, o teatro de revista brasileiro já havia sido bastante alimentado pela féerie europeia.

\section{Influência das trupes estrangeiras nas revistas nacionais}

Segundo Laura Cascaes, após a visita da Velasco, "as revistas cariocas passaram a fazer referências desde trajes típicos espanhóis até trajes flamencos" (CASCAES, 2009, p. 105). Em 1928, dois ex-integrantes da companhia fixaram residência no Rio de Janeiro. Lou e Janot atuaram em diversas revistas e chegaram a ser contratados como bailarinos e coreógrafos pela Companhia Margarida $\mathrm{Max}^{22}$ (CASCAES, 2009). A importância da presença e do trabalho dos dois pode ser conferida pelos destaques recebidos durante a divulgação do espetáculo Femina nos jornais (Figura 10). Atingir o padrão europeu de qualidade plástica era uma meta para o teatro de revista brasileiro.

\section{Figura 10: Divulgação do espetáculo Femina.}

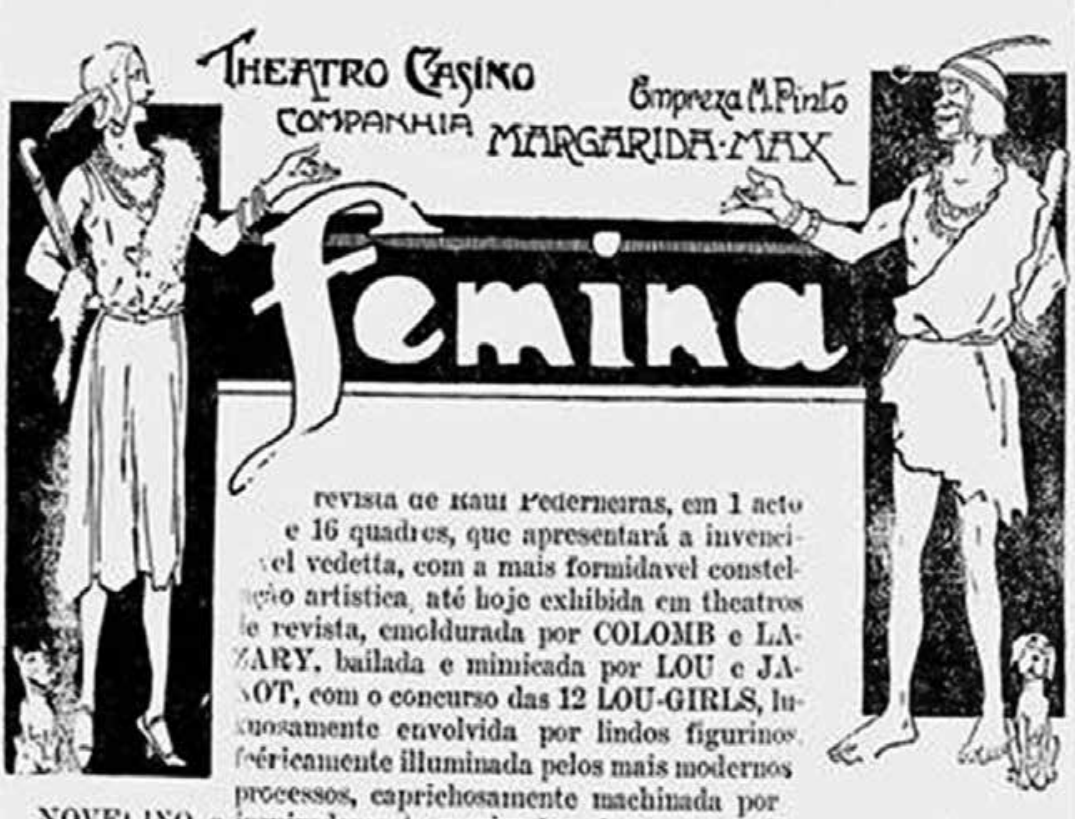

NOVELINO $e$ prosiras eaprichosanente machinada por

explendidame inspiradamente musiea da pelos nossos melhores conyositores,

NEZ GRAU

Estréa Sabbado 19, em 3 sess6́zs, à 19/45-21ן15 e 22,30 3 sess6zs

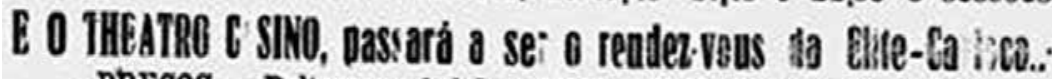
PREços - Poltromas e balobes, ssc00 - Frizas e camarotes, 255000.

Fonte: Jornal A Batalha. Edição de 17 de abril de 1930.

A propósito da estreia do espetáculo Femina, o jornal A Batalha publicou o seguinte, na seção Drama Comédia Revista:

A Velasco e a Rasimi vieram fazer um bem, ou um mal? Por que foi só depois da vinda ao Brasil de esses dois elencos que os empresarios cariocas se resolveram a modificar o systema antigo de fazer revistas. Eram melhores ou peores? Fica a opinião de cada um com cada qual. Do que se cogita saber é que foi M. Pinto quem 
primeiro apresentou as revistas-feeries, revistas encantadas e de moldes diferentes aos até então estabelecidos. E venceu: venceu no Carlos Gomes, venceu no antigo São Pedro, venceu em São Paulo, venceu em toda a parte onde a Companhia Margarida Max se apresentou e sempre para triumphar. (A BATALHA, edição de 19 de abril de 1930, p. 6. Foi mantida a grafia original)

Esse foi um aspecto importante de mudança na produção revisteira, que nas décadas seguintes passou a se preocupar cada vez mais com o acabamento e a qualidade dos cenários e figurinos, com a beleza das mulheres e em manter uma unidade plástica no espetáculo. Tal unidade se revelava também no corpo das mulheres. Com a maior exposição do corpo, as coristas que antes podiam ser "gorduchinhas e desengonçadas" (COLLAÇO, 2008a, p. 237) perderam a vez para mulheres com corpos esculturais, numa beleza padronizada. Estas ganharam mais espaço na cena na medida em que o apelo erótico mais explícito ganhou força.

As mulheres tiravam as meias, exibiam pernas e seios, e o nu feminino deixava de ser estático para ganhar novas dimensões e proporções na cena. Vera Collaço identifica, nessa época, um "recuo do pudor"24 relacionado ao corpo feminino revisteiro, e aborda "como o afrouxamento das coerções e o fortalecimento da visibilidade, exposição e do prazer proporcionado pelo corpo sexuado e sensual, foram apropriados e retrabalhados no palco revisteiro através de suas vedetes e girls" (COLLAÇO, 2008b, p. 2). A autora avalia ainda que "a apropriação, por parte dessas artistas, de seu próprio corpo para 0 prazer e a sensualidade, servia de reverberação máxima ao que se percebia no corpo social" (idem, p. 2). Em relação a essa dicotomia entre o corpo teatral e o social, considera que estando no palco, expondo-se à visibilidade, as vedetes e girls fazem avançar a fronteira do pudor mais rapidamente que no social, ganhando, dessa maneira,

espaço e autonomia para tomar conta de seu corpo, para mostrar seu corpo, para achar uma brecha dentro da sociedade encabeçada por homens que a circundava, brecha essa ao se assumir como "objeto de desejo" (...) Ela se assume como uma mulher irresistivel e encantadora, além do desenvolvimento do seu papel como atriz, e toma conta da revista de maneira arrebatadora, não apenas lado-a-lado com os grandes atores cômicos, mas indo além, ocupando mais e mais espaços no palco. (COLLAÇO, 2009, p. 7)

A partir de 1940, com a Cia. Walter Pinto, a presença feminina ganha maior destaque nos palcos do que a alusão política. 0 empresário exerceu importantíssimo papel na cena revisteira da época ao imprimir visão atualizada no modelo féerie, dando-Ihe novo fôlego mediante constantes investimentos, fosse em aparatos tecnológicos, fosse em formação de equipe especializada. Seus espetáculos contavam com o que havia "de melhor no campo do teatro musicado da época, tanto em termos de aparatos cenográficos, de efeitos especiais de luz, som, etc. quanto de equipes técnicas e artísticas conceituadas" (CHIARADIA, 2011, p. 63).

Em sua companhia, as vedetes tinham posição de destaque. Ele as treinava para que cantassem, improvisassem, se dirigissem com desembaraço à plateia, contassem piadas e fossem sensuais (Figura 11). Veneziano (2011) destaca que Walter Pinto se tornou uma lenda, e também uma estética, ao transformar o teatro de revista em algo espetacular e deslumbrante - antes dele, o que os empresários buscavam nas vedetes era o sex appeal, lançando-as nos espetáculos com pouco preparo, e apostando em sua beleza física e seu talento natural. Já o empresário valorizou as vedetes de tal maneira em cena, que "elas conquistaram o público superando, em popularidade, os cômicos" (VENEZIANO, 2011, p. 66). 
Figura 11: Apoteose do 1ํato da revista Muié Macho, sim sinhô

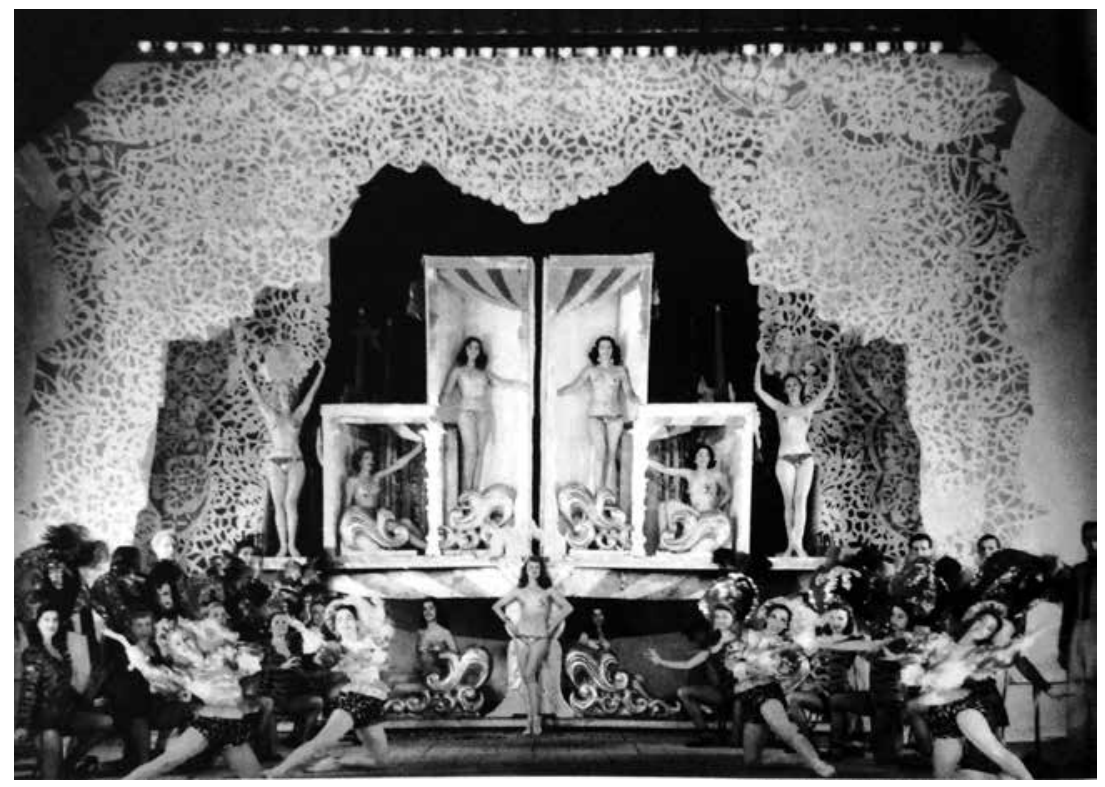

Fonte: CHIARADIA, 2011, p. 92.

A autora nos lembra que o sucesso de uma vedete não dependia apenas da beleza, era preciso saber cantar, ter empatia com o público, desembaraço ao contar piadas, e que era necessário desempenhar várias funções, subindo degrau por degrau na carreira, até chegar ao posto de vedete. Porém, ter atributos físicos como beleza e gingado era fundamental, assim como malícia e sensualidade.

Após a transformação produzida na cena por Walter Pinto, o teatro de revista progressivamente foi se tornando show de boate, voltado principalmente para o desempenho da vedete:

\footnotetext{
Nestes shows de boate, a vedete ganhou novo significado. Se no teatro de revista esta figura dividia as atenções com cômicos, filas de bailarinos, efeitos especiais e bons textos revisteiros, nos shows de boate, ela estará quase só, em primeiríssimo plano, em um espaço muito menor. Neste caso, portanto, o corpo escultural tornou-se 0 atributo primordial. Em seguida, vinham a malícia, a sensualidade, a postura, a comunicação com o público. Já não era mais necessária a bela voz, qualidade que acrescentaria, somente, uma vantagem. (VENEZIANO, 2011, p. 68)
}

A partir da década de 1960, a revista perde força como gênero específico, sofrendo fragmentações e se dividindo em várias vertentes: uma parte se transformou em programas humorísticos na televisão; outra, se bifurcou entre shows tipo exportação e teatro de bolso, desaparecendo em seu formato mais exuberante (VENEZIANO, 2013).

\section{Considerações finais}

0 corpo feminino, vestido ou não, torna-se o elemento fundamental do espetáculo e, dessa maneira, configura-se como moeda de valor, como capital simbólico. Faço aqui uma aproximação ao conceito de Pierre Bourdieu, considerando que o capital simbólico "corresponde ao conjunto de rituais de reconhecimento social, e que compreende o prestígio, a honra etc." (THIRY-CHERQUES, 2006, p. 39). 0 conceito de capital em Bourdieu é derivado da noção econômica, logo seu acúmulo demanda investimento. 0 capital econômico abrange bens, patrimônio, trabalho; é diretamente relacionado ao dinheiro, às riquezas materiais. Além do capital econômico e do capital simbólico, Bourdieu categoriza ainda o capital cultural e o social - correspondentes, 
respectivamente, ao "conjunto de qualificações intelectuais produzidas e transmitidas pela família, e pelas instituições escolares" e ao "conjunto de acessos sociais, que compreende o relacionamento e a rede de contatos" (idem). Importante notar que as formas de capital são conversiveis, o que significa, por exemplo, que o capital simbólico pode se converter em capital econômico e vice-versa. Esse é um importante ponto dessa linha de raciocínio, já que as atrizes eram profissionais que em sua grande maioria sobreviviam do trabalho no teatro.

Acredito que a valorização da mulher na cena revisteira desde o início do século $X X$ se dá a partir do olhar masculino. Vera Collaço associa a crescente exposição do corpo feminino a uma "coisificação, com um corpo explorado apenas como um produto barato, tal como é perceptível na história deste gênero teatral no Brasil" (COLLAÇO, 2008b, p. 2). Eu discordo. Parece-me que o corpo feminino no teatro de revista é produto caro - na realidade, chega a ser talvez o maior valor que uma atriz possa ter. Nesse sentido, as vedetes e girls se apropriam do seu próprio corpo para o prazer e a sensualidade (situação anteriormente reprimida), apoderando-se de seus espaços de atuação e representação como forma de garantir novos espaços sociais e autonomia.

[Recebido em: 26/01/2016]

[Aprovado em: 22/03/2016]

\section{NOTAS}

[1] Manifestacão teatral geralmente realizada nas feiras francesas entre os séculos XVII e XVIII, que misturava vários estilos, técnicas e formas de espetáculo buscando promover o divertimento calcado no gosto popular. (CAMARG0, 2012)

[2] Classificação ou posto que o artista ocupa numa companhia de acordo com o gênero do papel que vai representar. (ARANHA, 1949)

${ }^{[3]} 0$ papel desempenhado por um ator ou uma atriz podia mudar por causa de sua idade. Uma ingênua, por exemplo, podia eventualmente ocupar a posição de uma dama, e ai se manteria.

${ }^{[4]}$ Disponivel em: <http://memoria.bn.br/DocReader/DocReader.aspx?bib=030015_04\&tPagFis=15904>. Acesso em: 5 set. 2015. Foi mantida a grafia original.

${ }^{[5]}$ Disponivel em: <http://memoria.bn.br/DocReader/DocReader.aspx?bib=030015_04\&tPagFis=16186>. Acesso em: 5 set. 2015

${ }^{[6]}$ A Bataclan chamava as coristas de girls, e logo as companhias brasileiras, como a Tro-lo-ló, adotaram o termo: "Entre girls e coristas havia diferenças profissionais de postura e de técnicas. A função revisteira também era outra, pois de uma girl se esperava mais sensualidade que a simples brejeirice da corista" (FARIA, 2012, p. 442).

[7] 0 repertório da companhia à época era composto por cinco espetáculos: Paris-Chic, Pourvous plaire, V'la Paris, Au revoir e De toutes couleurs. Destes, apenas o último não foi apresentado no Rio de Janeiro e em São Paulo durante essa temporada.

${ }^{[8]}$ Mário Nunes foi crítico teatral e autor. Sua obra 40 anos de teatro reúne registros críticos publicados no Jornal do Brasil referentes às atividades cênicas cariocas do início do século XX.

${ }^{[9]}$ Disponivel em: <http://memoria.bn.br/DocReader/DocReader.aspx?bib=030015_04\&tPagFis=16588>. Acesso em: 5 set. 2015.

${ }^{[10]}$ Idem.

[11] Disponivel em: <http://memoria.bn.br/DocReader/DocReader.aspx?bib=030015_04\&tPagFis=15904>. Acesso em: 18 out. 2015.

${ }^{[12]}$ Disponivel em: <http://memoria.bn.br/DocReader/DocReader.aspx?bib=030015_04\&tPagFis=16888>. Acesso em: 18 out. 2015.

${ }^{[13]}$ Foram consultados, principalmente, o Jornal do Brasil, O Correio da Manhã e O País.

${ }^{[14]}$ Disponivel em: <http://memoria.bn.br/DocReader/DocReader.aspx?bib=030015_04\&tPagFis=23275>. Acesso em: 20 out. 2015.

${ }^{[15]}$ Disponível em: <http://memoria.bn.br/DocReader/docreader.aspx?bib=090972_07\&tPagFis=12840>. Acesso em: 10 nov. 2015.

[16] "Termo francês que vem de fée que quer dizer 'fada'. 0 termo passou a designar um gênero de espetáculos mágicos e deslumbrantes" (FARIA, 2012, p. 442). 
${ }^{[17]}$ Disponivel em: <http://memoria.bn.br/DocReader/DocReader.aspx?bib=030015_04\&tPagFis=21190\&tPesq=>. Acesso em: 18 out. 2015.

${ }^{[18]}$ Disponivel em: <http://memoria.bn.br/DocReader/DocReader.aspx?bib=030015_04CtPagFis=19499>. Acesso em: 5 set. 2015

${ }^{[19]}$ Disponivel em <http://memoria.bn.br/DocReader/DocReader.aspx?bib=259063\&PagFis=45980 $>$. Acesso em: 10 ago. 2015.

${ }^{[20]}$ Nesse mesmo ano, o Teatro São Pedro passa a chamar-se João Caetano, como é conhecido até os dias atuais. ${ }^{[21]}$ Disponivel em: <http://memoria.bn.br/DocReader/DocReader.aspx?bib=030015_04\&tPagFis=23279>. Acesso em: 10 ago. 2015.

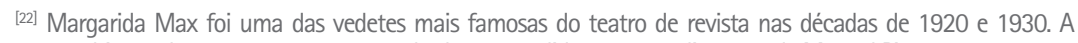
companhia que levava seu nome era um dos bem-sucedidos empreendimentos de Manoel Pinto.

${ }^{[23]}$ Revista de Raul Pederneiras para a Companhia Margarida Max, que estreou em 19 de abril de 1930.

${ }^{[24]}$ Expressão cunhada por Anne-Marie Sohn (COLLAÇO, 2008b, p. 2).

\section{REFERÊNCIAS}

ARANHA, José da Silva. Teatrologia. Rio de Janeiro: Editora 0 Construtor S/A, 1949

BRANDÃO, Tânia. A cidade do teatro e o teatro da cidade: imagens do Rio de Janeiro no teatro de revista dos anos 1920. In: Usos do Passado - XII Encontro Regional de História - ANPUH. Rio de Janeiro, 2006.

CAMARGO, Robson Corrêa de. 0 teatro de feira e sua poética. In: Rebento: revista de artes do espetáculo. Universidade Estadual Paulista Julio de Mesquita Filho, Instituto de Artes, n. 3, mar. 2012. São Paulo: Instituto de Artes, 2012. p. 62-81.

CASCAES, Laura Silvana Ribeiro. Queria bordar teu nome: a dança no teatro de revista. Florianópolis, 2009. Dissertação (Mestrado), Universidade do Estado de Santa Catarina - UDESC.

CHIARADIA, Filomena. Iconografia teatral: acervos fotográficos de Walter Pinto e Eugénio Salvador. Rio de Janeiro: FUNARTE, 2011.

COLLAÇO, Vera Regina Martins. As aparências mutantes de um corpo que se desnuda. In: Urdimento - Revista de Estudos em Artes Cênicas, Florianópolis: Programa de Pós-Graduação em Teatro da Universidade do Estado de Santa Catarina - UDESC/CEART, v. 1, n.11 (2008a), p. 231-241.

. 0 desnudar do corpo feminino. In: DA Pesquisa - Revista de Investigação em Artes, Florianópolis, Universidade do Estado de Santa Catarina, v.1, n. 3 (2008b)

. Ct SANTOLIN, Rosane Faraco. As vedetes, as coristas e as revistas! In: Anais do XIX Seminário de Iniciação Científica - V Jornada de Iniciação Científica. Universidade do Estado de Santa Catarina. Florianópolis, 2009.

FARIA, João Roberto (Org.) História do teatro brasileiro, volume I: das origens ao teatro profissional da primeira metade do século XX. São Paulo: Perspectiva: Edições SESCSP, 2012.

RANGEL, Otávio. Escola teatral de ensaiadores: da arte de ensaiar. Rio de Janeiro: Editora Talmagráfica, 1954, p. 29.

REIS, Angela de Castro. Cinira Polonio, a divette carioca: estudo da imagem pública e do trabalho de uma atriz no teatro brasileiro da virada do século XIX. Rio de Janeiro: Arquivo Nacional, 1999.

NUNES, Mário. Estréia da Companhia do Ba-Ta-Clan. Paris-Chic, revista de Roger Ferreol e José de Berys. In: Jornal do Brasil, 6 de agosto de 1922. Disponivel em: <http://memoria.bn.br/DocReader/DocReader. aspx?bib=030015_04ctPagFis=16588>. Acesso em: 18 out. 2015.

THIRY-CHERQUES, Hermano Roberto. Pierre Bourdieu: a teoria na prática. In: RAP Rio de Janeiro, 40 (1): 27-55, jan./fev. 2006.

VENEZIANO, Neyde. 0 teatro de revista no Brasil: dramaturgia e convenções. Campinas: Pontes: Editora da Universidade Estadual de Campinas, 1991.

. O teatro de revista no Brasil: dramaturgia e convenções. São Paulo: Sesi-SP Editora, 2013.

. 0 sistema vedete. In: Repertório, Salvador, n. 17, p. 58-70, 2011.2.

.É brasileiro, já passou de americano. In: Revista Poiésis, Niterói, n. 16, p. 52-61 


\section{REFERÊNCIAS DE ARQUIVOS DIGITAIS}

A Batalha, ano II, edição de 19 de abril de 1930. Disponível em: <http://bndigital.bn.br/hemerotecadigital/>. Acesso em: 30 maio 2015.

A Vida Moderna, várias edições de 1922, 1923, 1924, 1925 e 1926. Disponivel em: <http://bndigital. bn.br/hemeroteca-digital/>. Acesso em: 30 maio 2015.

Correio da Manhã, várias edições de 1922, 1923, 1924, 1925 e 1926. Disponivel em: <http://bndigital. bn.br/hemeroteca-digital/>. Acesso em: 30 maio 2015.

Correio Paulistano, várias edições de 1922, 1923, 1924, 1925 e 1926. Disponível em: <http://bndigital. bn.br/hemeroteca-digital/>. Acesso em: 30 maio 2015.

Jornal do Brasil, várias edições de 1922, 1923, 1924, 1925 e 1926. Disponivel em: <http://bndigital. bn.br/hemeroteca-digital/>. Acesso em: 30 maio 2015.

O Combate, várias edições de 1922, 1923, 1924, 1925 e 1926. Disponível em: <http://bndigital.bn.br/ hemeroteca-digital/>. Acesso em: 30 maio 2015.

O País, várias edições de 1922, 1923, 1924, 1925 e 1926. Disponível em: <http://bndigital.bn.br/ hemeroteca-digital/>. Acesso em: 30 maio 2015.

Revista Fon-Fon, várias edições de 1922, 1923, 1924, 1925 e 1926. Disponível em: <http://bndigital. bn.br/hemeroteca-digital/>. Acesso em: 30 maio 2015. 